\title{
Porcine pluripotent stem cells and their differentiation
}

\author{
Toshihiko Ezashi ${ }^{1,2}$ and R. Michael Roberts ${ }^{1,2,3,}$ \\ ${ }^{1}$ Division of Animal Sciences, University of Missouri, Columbia, MO 65211; ${ }^{2}$ Bond Life Sciences \\ Center, University of Missouri, Columbia, MO 65211; ${ }^{3}$ Department of Biochemistry, University of \\ Missouri, Columbia, MO 65211, U.S.A.
}

In some situations, the pig has advantages over the mouse as a model in biomedical research. The availability of pluripotent cell lines is likely to broaden this appeal. Here we review progress in the derivation and characterization of embryonic stem cells (ESC) and induced pluripotent lines (iPSC) from pigs. Until recently, most porcine ESC failed to meet the full criteria for pluripotency, but that may be changing as more becomes known about the culture conditions required to maintain epiblast outgrowths from early porcine conceptuses in an undifferentiated, selfrenewing state. In addition, porcine iPSC cells have been generated, some with the features of FGF2-dependent epiblast-type cells, typified by human ESC, and others that require LIF and resemble the "ground state", naïve-type mouse ESC. Despite these successes, incomplete reprogramming and loss of pluripotency when selection conditions are relaxed continue to be problems that must be overcome if the full potential of iPSC is to be realized. The most immediate value of iPSC may relate to their ability to proliferate almost indefinitely in culture, thus enabling more complex genetic manipulations of the genome through growth selection than could be performed in other cell types. The "undifferentiated" state of iPSC may also allow improved cloning efficiency, although this remains to be proved. Finally, the pig will likely prove useful in testing stem cell-based therapies, although only a limited number of experiments demonstrating that the porcine iPSC can be directed to transform into more specialized sub-lineages and then form functional grafts have been performed.

\section{Embryonic stem cells (ESC) from swine}

The pursuit of ESC from swine has a long history originating back to the early 1990s (Notarianni et al. 1990), a time not long after the introduction of mouse ESC, which had first been reported earlier in the decade (Evans \& Kaufman 1981, Martin 1981). Since their establishment, mouse ESC began to revolutionize developmental genetics by permitting changes, usually loss-offunction mutations, but later a variety of other modifications, to be introduced at preselected genetic loci in the mouse genome through homologous recombination (Capecchi 1989, Koller \& Smithies 1992). In this regard, mouse ESC exhibited three crucial properties. First, they were able to differentiate into derivatives of all three germ layers (ectoderm, endoderm, and mesoderm) within embryoid bodies and teratomas. Second, their more-or-less infinite lifespan provided the extended times required for positive and negative selection to ensure that a 
mutation had been introduced at the correct gene locus. Finally, mouse ESC had the ability, after genetic modification, to colonize the inner cell mass of the blastocyst, thereby giving rise to chimeras, and, at a frequency that was mouse strain-dependent, contributing to the gonads and gametes of any offspring born.

Undoubtedly, one impetus for the early attempts to generate porcine ESC was for the same purpose, namely to use the cells to introduce precisely delivered genetic changes into pigs. Yet, this was not to be. Cell lines with some features of ESC were derived from porcine blastocysts (Wheeler 1994, Chen et al. 1999, Li et al. 2003) and particularly embryonic germ cells (Shim et al. 1997, Piedrahita et al. 1998, Rui et al. 2004). Some of these cells were also able contribute to F1 generation chimeras, although not to the germ line (Shim et al. 1997, Piedrahita et al. 1998, Chen et al. 1999, Mueller et al. 1999, Rui et al. 2004, Vassiliev et al. 2010). For the most part, however, the cell lines did not meet the full criteria for pluripotency that had been demonstrated by their mouse homologs (Brevini et al. 2007, Vackova et al. 2007, Talbot \& Blomberg le 2008). One reason for these difficulties was almost certainly the unsuitability of the growth media needed to support the cells and the reliance on growth factors whose use was adopted from studies on rodent and primate cells. It is also clear from mouse studies that not all strains are equally competent to give rise to ESC from embryo outgrowths. Pigs and other ungulates may fall within such a similarly "difficult" category. It is also likely that investigators felt that the investment in time and funds to generate chimeras initially and the subsequent F2 heterozygotes and F3 homozygotes was a daunting task. Nevertheless, recent reports indicate that the production of genuine porcine ESC may be within reach (Alberio et al. 2010, Aller et al. 2010, Vassiliev et al. 2011, Wolf et al. 2011, Alberio \& Perez 2012, Haraguchi et al. 2012, Tan et al. 2012), particularly if the ESC are generated from epiblast cells of slightly older conceptuses rather than the ICM of early stage blastocysts (Alberio \& Perez 2012).

\section{Induced pluripotent stem cells (iPSC) from swine}

As discussed above, derivation of ESC from pigs and other livestock became a potentially important consideration because it offered an attractive alternative to pronuclear injection as a means for creating genetically modified animals. The discovery that somatic cells from mice (Takahashi \& Yamanaka 2006) and later, humans (Takahashi et al. 2007, Yu et al. 2007), could be re-programmed to pluripotent cells by introducing a limited set of genes, made iPSC possible surrogates for ESC in this regard. The first iPSC from the pig were reported in 2009 (Esteban et al. 2009, Ezashi et al. 2009, Wu et al. 2009). In general, similar approaches were employed for porcine cells as had been applied to mouse and human cells (Table 1). Somatic cells, usually fibroblasts, were transfected with either lentiviral or retroviral vectors carrying standard "Yamanaka factors" transgenes (PSKM in Table 1). As with the mouse and human iPSC that preceded them, colonies formed, albeit inefficiently, and could be picked as clonal lines within 2-4 weeks. These colonies were compact and relatively flattened and resembled human ESC and iPSC in morphology (Fig. 1A) rather than analogous stem cells from mouse. They expressed the expected porcine genes indicative of pluripotent stem cells, and, similar to the human ESC and iPSC, they were dependent for maintenance of pluripotency on basic FGF (FGF2) and ACTIVIN/NODAL/TGFB signaling (Alberio et al. 2010) rather than LIF. These pig iPSC were, therefore, of the epiblast, sometimes called the primed (see Table 1) type rather than the naïve type, which are classically derived from the inner cell mass. The latter form smaller, dome shaped, colonies, depend on LIF/STAT signaling, and can be dissociated readily into single cells by trypsin, features that we explore further below. The epiblast/primed phenotype seen with pig iPSC is a major shortcoming, as porcine iPSC, like human ESC and iPSC, tend to 
Table 1. Summary of pluripotent cell types, derivation methods and culture conditions for porcine iPSC

\begin{tabular}{|c|c|c|c|}
\hline Cell type & $\begin{array}{l}\text { Delivery method ( } R \\
\text { factors) }\end{array}$ & Medium components and feeder cells & References \\
\hline EpiSC & Viral (PSKM) & FBS/DMEM, FGF2 or LIF on MEF & (Esteban et al. 2009) \\
\hline EpiSC & Viral (PSKM) & KSR/DF12, hFGF2 on MEF & $\begin{array}{l}\text { (Ezashi et al. 2009), (Wu et } \\
\text { al. 2009)*, (West et al. 2010), } \\
\text { (Yang et al. 2012), (Gu et al. } \\
\text { 2012)**, (Hall et al. 2012)** }\end{array}$ \\
\hline EpiSC & $\begin{array}{l}\text { Plasmid or Viral } \\
\text { (PSKM) }\end{array}$ & $\begin{array}{l}\text { Mix }(1: 1) \text { of human ESC medium and mouse } \\
\text { ESC medium on MEF }\end{array}$ & $\begin{array}{l}\text { (Montserrat et al. 2011), } \\
\text { (Montserrat et al. 2012) (SKM) }\end{array}$ \\
\hline EpiSC & $\begin{array}{l}\text { Sleeping Beauty } \\
\text { transposon }\end{array}$ & (PSKM) KSR/DF12, FGF2 on MEF or SNL & (Kues et al. 2012) \\
\hline Naïve & Plasmid, (PSKMNLT) & $\begin{array}{l}\text { KSR/DF12, hLIF, } 2 \text { inhibitors (PD/CH) on } \\
\text { MEF }\end{array}$ & (Telugu et al. 2010) \\
\hline Naïve & Viral (PK) & $\begin{array}{l}\text { KSR/DF12, hLIF, } 2 \text { inhibitors }(\mathrm{KP} / \mathrm{CH}) \text { on } \\
\text { MEF }\end{array}$ & (Telugu et al. 2011) \\
\hline Naïve & Viral (PSKM) & KSR/DMEM, hLIF on SNL & (Thomson et al. 2012)** \\
\hline Naïve & Viral (PSKM) & FBS/DMEM, FGF2, LIF on MEF & (Cheng et al. 2012) \\
\hline Naïve & Viral (PSKM) & FBS/DMEM, pLIF, FK & (Fujishiro et al. 2012) \\
\hline Naïve & Viral (PK) & $\begin{array}{l}\text { FBS or KSR/DF12, hLIF, } 5 \text { inhibitors (NaB, } \\
\mathrm{SB}, \mathrm{PD}, \mathrm{FK}, \mathrm{CH}) \text { on MEF }\end{array}$ & (Liu et al. 2012) \\
\hline Naïve & Viral (PSKM) & $\begin{array}{l}\mathrm{FBS}+\mathrm{mLIF} \text { [generation] then mLIF, } \\
3 \text { inhibitors (PD/CH/PD1) in N2B27 } \\
\text { [maintenance] on MEF }\end{array}$ & (Rodriguez et al. 2013) \\
\hline unclear & Oocyte extracts & unclear (described only as "ES medium") & (Bui et al. 2012) \\
\hline
\end{tabular}

EpiSC are epiblast (also known as "primed") type pluripotent stem cells); Naïve are iPSC with a phenotype similar in phenotype to the authentic ESC derived from the ICM of mice.

*: FGF2 was not included. **: knockout DMEM, R factors: reprogramming factors, P: POU5F1 (OCT4), S: SOX2, K: KLF4, M: cMYC, N: NANOG, L: LIN28, T: T-antigen, FBS: Fetal Bovine Serum, DMEM: Dulbecco's Modified Eagle's Medium, DF12: DMEM/Nutrient Mixture F-12, MEF: mouse embryonic fibroblasts, SNL: STO fibroblasts stably transfected with mLIF expression vector, KSR: knockout serum replacement, h: human, m: mouse, p: porcine, LIF: Leukemia Inhibitory Factor, FGF2: Basic fibroblast growth factor, PD: PD0325901, CH: CHIR99021, PD1: PD173074, KP: Kenpaullone, NaB: sodium butylate, SB: SB43152, FK: forskolin

die when dissociated into single cells and are usually propagated as clumps. They also grow more slowly than ICM-derived mouse ESC and exhibit poorer plating and freezing efficiencies.

Since the original reports in 2009, several more porcine iPSC cell lines have been described, including ones created with non-integrating vectors (Telugu et al. 2010) and different combinations of reprogramming genes (Table 1). Other than some inconsistencies in the relative presence of certain cell surface carbohydrate antigens, e.g. SSEA 1,3 , \& 4, the general phenotypes of the epiblast-type lines so far described are quite similar. They have been demonstrated to be pluripotent, as evidenced by their ability to differentiate into tissue types reflective of the three germ layers within either embryoid bodies or teratomas, and to survive extended numbers of cell doublings without demonstrating senescence. As discussed later, there have only been limited studies on directed differentiation towards specific kinds of tissues and whether they can become integrated into chimeras, topics discussed in later sections below. However, directed differentiation has been achieved in only a limited number of cases by applying protocols adopted from studies with human ESC and iPSC (Table 2). 

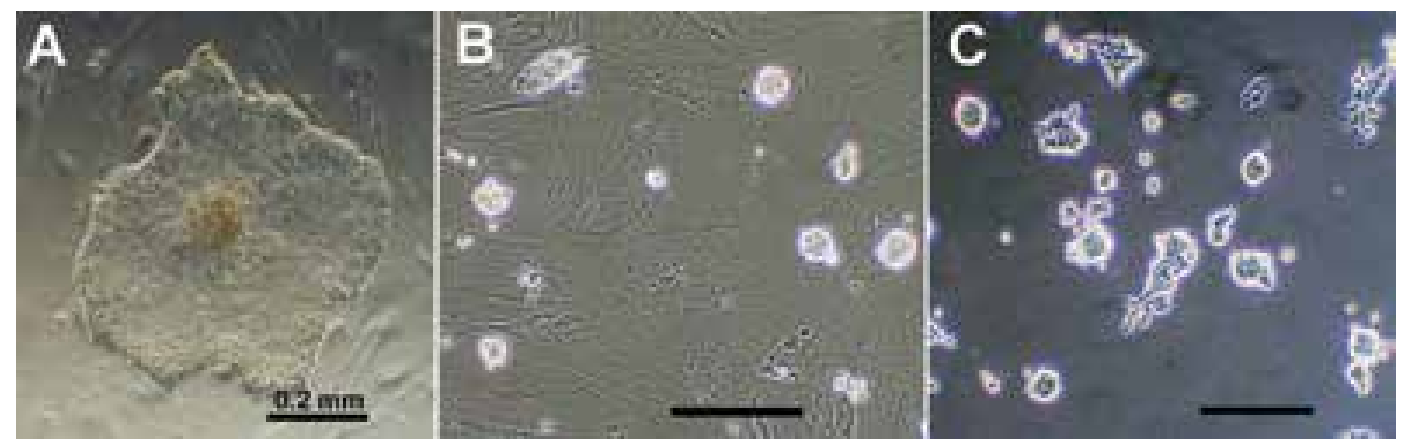

Fig. 1. Typical morphological features of three types of porcine iPSC (A) A colony of porcine iPSC reprogrammed fibroblasts with four factors (POU5F1, SOX2, KLF4 and CMYC) through lentivial transduction and FGF2 supplemented medium on a feeder layer of mouse embryonic fibroblasts (MEF) (Ezashi et al 2009). (B) Colonies of naïve-type porcine iPSC reprogrammed fibroblasts with seven factors delivered through episomal plasmids and selected on Leukemia Inhibitory Factor (LIF)-based, 2i medium on MEF feeders (Telugu et al 2010). (C) Colonies of naïve-type porcine iPSC cells derived from the inner cell mass of porcine blastocysts re-programmed by delivery of two factors (POU5F1 and KLF4) by using lentiviral transduction and LIF-based, $2 \mathrm{i}$ medium. The image is of cells maintained under feeder free condition (Telugu et al 2011). All bars, $0.2 \mathrm{~mm}$.

Table 2. Directed differentiations of piPSC

\begin{tabular}{|c|c|c|c|}
\hline Target cell type & Evaluation & Transplantation & Reference \\
\hline rod photoreceptor & $\begin{array}{l}\text { RT-PCR, immunostaining, } \\
\text { integration and projections into } \\
\text { the retina }\end{array}$ & $\begin{array}{l}\text { subretinal space of } \\
\text { pig eyes }\end{array}$ & $\begin{array}{l}\text { (Zhou et al. } \\
\text { 2011) }\end{array}$ \\
\hline $\begin{array}{l}\text { neural differentiation (motor neuron, } \\
\text { astrocyte, oligodendrocyte) }\end{array}$ & RT-PCR, immunostaining & NA & $\begin{array}{l}\text { (Yang et al. } \\
\text { 2012) }\end{array}$ \\
\hline endotherial cells & $\begin{array}{l}\text { echocardiography, MRI, } \\
\text { paracrine factors }\end{array}$ & $\begin{array}{l}\text { mice with myocardial } \\
\text { infarction }\end{array}$ & (Gu et al. 2012) \\
\hline $\begin{array}{l}\text { neuronal ectoderm, pancreatic cell, } \\
\text { cardiomyocyte/endotherial cell }\end{array}$ & immunostaining & NA & (Bui et al. 2012) \\
\hline
\end{tabular}

\section{Naïve versus epiblast-type stem cells}

The observation that human ESC obtained from ICM outgrowths differed in morphology, growth factor requirements, and other aspects of their phenotype from ICM-derived mouse ESC raised questions about the nature of pluripotency and the gene networks that supported it. This puzzle was partially addressed after a different kind of mouse ESC was produced from the epiblast of gastrulation-stage mouse conceptuses (Brons et al. 2007, Tesar et al. 2007). This new variety of mouse ESC resembled human ESC in colony morphology, required activin A and FGF2 rather than LIF, and has been called "primed" or epiblast stem cell (EpiSC) (Nichols \& Smith 2009, Hanna et al. 2010b). Mouse EpiSC and naïve ESC can be inter-converted by adjusting signaling networks through use of inhibitors and growth factor selection on LIF-containing versus FGF2-containing media (Bao et al. 2009, Greber et al. 2010, Hanna et al. 2010a, Xu et al. 2010). Together, these data confirmed that the two pluripotent states are distinct and respond differently to directing stimuli.

From the point of view of their utility as experimental models, naïve cells may have certain advantages over EpiSC. They exhibit among the highest rate of in vitro proliferation of any known 
mammalian cell, tend not to differentiate spontaneously (a frequent problem with EpiSC), can be dissociated into single cells without undergoing apoptosis, and can be efficiently cryopreserved. Finally, they are competent for producing germ-line chimeras, whereas mouse EpiSC are not (Brons et al. 2007, Tesar et al. 2007). On the other hand, there are reports of production of chimeric offspring from EpiSC in pigs (West et al. 2010, West et al. 2011), an observation that is somewhat surprising in view of the data from mice and the fact that EpiSC only survive well as clumps, which cannot be injected readily into embryos. It should be stressed that chimera formation may not in itself be an adequate criterion for defining the naïve pluripotent state because porcine EpiSC type of iPSC (West et al. 2010, West et al. 2011) and primitive mouse neural stem cells (Clarke et al. 2000, Karpowicz et al. 2007) can contribute to embryogenesis after introduction into pre-implantation conceptuses.

As a result of the limitations of EpiSC, there has been a recent focus on producing naïve type cells from this species (Table 1) by making use of approaches that led to the successful isolation of naïve type ESC from rat (Buehr et al. 2008, Li et al. 2008) and "difficult" strains of mouse (Hanna et al. 2009). The strategy has generally been to select cells after transduction with reprogramming vectors on a LIF-based medium in presence of various pharmacological agents that differentially inhibit or activate signaling pathways that distinguish naïve from EpiSC. For example CHIR99021 (CH) activates the WNT signaling pathway and bye-passes MYC function, while kenpaullone (KP) appears to enhance the action of endogenous KLF4, a transcription factor that is poorly expressed in porcine epiblast-type iPSC (Telugu et al. 2010, Telugu et al. 2011). Others have incorporated PD0325901 into their mix of selection agents to inhibit ERK-mediated pathways (Huang et al. 2011) and forskolin (FK) to induce KLF4 and KLF2 expression (Hanna et al. 2010a). While some naïve type porcine iPSCs have been generated and maintained with two (Telugu et al. 2011, Ezashi et al. 2012) or more (Liu et al. 2012, Rodriguez et al. 2012) pharmacological agents present (Fig. 1B, C), such a cocktail of inhibitors may be dispensable (Fujishiro et al. 2013, Thomson et al. 2012). Instead, the crucial component of the medium may be LIF itself, with the porcine protein being more effective than its human or mouse homologues (Fujishiro et al. 2013).

As shown in Table 1, various reprogramming and culture conditions have been used to generate porcine iPSC, but a lack of silencing of the exogenous transgenes has invariably been observed, despite the concomitant up-regulation of endogenous pluripotency markers. Other indicators of complete re-programming, for example reactivation of $\mathrm{X}$ chromosome in female cells (Fujishiro et al. 2013) has generally not been pursued. Incompletely reprogrammed iPS cells (pre-iPSC) are hypothesized to maintain expression of exogenous transgenes with insufficient expression of endogenous pluripotent genes (Silva et al. 2008). In addition, down regulation of the ectopically-introduced transgenes, e.g., by tetracycline withdrawal for Tet-inducible expression vectors, often appears to lead to the loss of ESC-like phenotype (Wu et al. 2009, Chen et al. 2013). The presence of FBS in the culture medium used in the reprogramming stage has been implicated in favoring pre-iPSC in mice (Chen et al. 2013), because it contains growth factors of the BMP family that cause alterations of H3K9 methyltransferase and demethylase activities. The alternative use of Dulbecco's Modified Eagle's Medium (DMEM) supplemented with knockout serum replacement (KSR) medium (named iSF1) (Chen et al. 2010) improves the efficiency of "true" iPSC generation (Chen et al. 2013). Of course, findings from mouse cells may not be applicable to improving reprogramming condition for porcine iPSC, but it seems possible that the differences of DNA methylation status of the endogenous POU5F1 promoter observed between porcine iPSC reprogrammed in KSR (Wu et al. 2009) and FBS (Fujishiro et al. 2013) -supplemented media is due to FBS interference with re-programming in the latter. It will require further research to determine the ideal culture conditions in which to generate 
and then maintain a stable pluripotent status of porcine iPSC and ESC and whether or not these cells demonstrate the features that have made mouse ESC of the naïve type so useful.

\section{Potential utility of iPSC from swine}

\section{a) Genetic Modification}

As discussed earlier the mouse has come to dominate the field of mammalian genetics and specifically genetic modification to study gene function and provide disease models. A major disadvantage of mouse models, however, is that they often fail to recapitulate particular human disease phenotypes. This problem has prompted the use of larger animals, including the pig, which is often a better model than the mouse because of its larger size, longer life span, and a host of physiological and anatomical parameters that resemble those of humans better than rodents.

Genetic modification in swine has proceeded quite rapidly over the last decade (Matsunari \& Nagashima 2009, Whyte \& Prather 2011, Staunstrup et al. 2012), especially because of the viewed potential of pigs for providing organs for xenotransplantation (Klymiuk et al. 2010) and as models for studying the pathophysiology of human diseases, such as cystic fibrosis (Rogers et al. 2008), where mice fail to develop the relevant symptoms encountered in human patients. Ironically, few of these modifications, with the possible exception of swine expressing salivary phytase (Golovan et al. 2001), have made a contribution to agriculture. Moreover, to date, neither porcine ES like cells nor iPSC have been used to engineer any of the targeted gene loci. Instead investigators have resorted to somatic cells, usually fetal fibroblasts, which can be used for this purpose provided that the desired genetic change can be selected before the founder cells senesce. One weakness of somatic cells is that they are not pluripotent and cannot be employed to generate chimeric offspring. Instead, the nuclei of such cells are employed as donors in somatic cell nuclear transfer (SCNT) to create cloned, founder animals carrying one copy of the mutant gene. The hope is that pluripotent cells could have advantages over somatic cells for SCNT, because they are able to proliferate almost indefinitely, thus enabling more complex genetic changes to be performed. Additionally, their "undifferentiated" state may allow efficient reprogramming in the oocyte cytoplasm, hence improving livestock cloning efficiency, in general. Such possibilities have yet to be fully tested, but a recent report suggests that they may be poorer nuclear donors than embryonic fibroblasts unless the continued expression of the reprogramming transgenes can be silenced (Fan et al. 2013).

\section{b) Differentiation}

It is clear from the earlier discussion (see Table 1) that all the porcine iPSC so far described are pluripotent by the two most commonly used criteria, namely an ability to form embryoid bodies and teratomas that contain tissue types representing the three main germ layers. In a few cases, iPSC seem capable of contributing to chimeras (West et al. 2010, Fujishiro et al. 2013). There have been only a limited numbers of experiments demonstrating that the cells can be directed in vitro to transform into more specialized sub-lineages that might be tested for ability to form functional grafts in pigs. In one example, primed type iPSCs derived from pig fetal fibroblasts (Ezashi et al. 2009) were directed along the ectoderm lineage to form a mixture of cells that included rod photoreceptor lineage cells (Zhou et al. 2011). These cells when injected into the eye were able to integrate into the retina, differentiate into photoreceptors, and generate outer segment-like projections (Zhou et al. 2011) (Table 2). A limited number of other papers 
have demonstrated analogous directed differentiation in vitro (Bui et al. 2012, Yang et al. 2012) (Table 2), but the work so far has, in general, been very limited in scope.

\section{c) Efficacy and Safety models for tissue regeneration}

Swine have had an important role in biomedical research for decades (Swindle 2007), particularly to study cardiovascular disease, atherosclerosis, obesity and lipoprotein metabolism, wound and burn repair, intestine and immune system development. As a large animal model, the pig has several potential advantages over the mouse for predicting whether or not stem cell-based therapy is likely to be safe when considering outcomes, such as toxicity, immune responses, migration of cells to out of target sites, and tumorigenicity. They can also be used to explore surgical techniques and cell delivery procedures, and for optimizing the number and type of cells to be used for a particular type of graft. Pigs have already been treated with a variety of "adult" stem cells to determine whether cardiac function can be improved after induced ischemia (Amado et al. 2006, Gandolfi et al. 2011, Mazhari \& Hare 2012). Although positive outcomes have been reported, the precise mechanisms whereby amelioration is accomplished remains unclear. Recently, pig iPSC, after conversion to endothelial cell precursors, have been successfully transplanted into mice with myocardial infarctions and appeared to promote neovascularization in the ischemic regions (Gu et al. 2012) (Table 2). Presumably, the next step will be to test pigs by comparable procedures and confirm the budding potential of the iPSC approach.

\section{Acknowledgements}

Research was supported by NIH Grant HD-069979 and the Food for the $21^{\text {st }}$ Century Program at the University of Missouri. We thank Dr. Bhanu Telugu of the University of Maryland for his in-put and Mr. D. Reith for editing the manuscript.

\section{References}

Alberio R, Croxall N \& Allegrucci C 2010 Pig epiblast stem cells depend on activin/nodal signaling for pluripotency and self-renewal. Stem Cells Dev 19 1627-1636.

Alberio R \& Perez AR 2012 Recent advances in stem and germ cell research: implications for the derivation of pig pluripotent cells. Reprod Domest Anim 47 Suppl 4 98-106.

Aller JF, Cancino AK, Rebuffi GE \& Alberio RH 2010 Effect of estradiol benzoate used at the start of a progestagen treatment on superovulatory response and embryo yield in lactating and non-lactating Ilamas. Anim Reprod Sci 119 322-328.

Amado LC, Schuleri KH, Saliaris AP, Boyle AJ, Helm R, Oskouei B, Centola M, Eneboe V, Young R, Lima JA, Lardo AC, Heldman AW \& Hare JM 2006 Multimodality noninvasive imaging demonstrates in vivo cardiac regeneration after mesenchymal stem cell therapy. J Am Coll Cardiol 48 2116-2124.

Bao S, Tang F, Li X, Hayashi K, Gillich A, Lao K \& Surani MA 2009 Epigenetic reversion of post-implantation epiblast to pluripotent embryonic stem cells. Nature
461 1292-1295.

Brevini TA, Antonini S, Cillo F, Crestan M \& Gandolfi F 2007 Porcine embryonic stem cells: Facts, challenges and hopes. Theriogenology 68 Suppl 1 S206-S213.

Brons IG, Smithers LE, Trotter MW, Rugg-Gunn P, Sun B, Chuva de Sousa Lopes SM, Howlett SK, Clarkson A, Ahrlund-Richter L, Pedersen RA \& Vallier L 2007 Derivation of pluripotent epiblast stem cells from mammalian embryos. Nature 448 191-195.

Buehr M, Meek S, Blair K, Yang J, Ure J, Silva J, McLay R, Hall J, Ying QL \& Smith A 2008 Capture of authentic embryonic stem cells from rat blastocysts. Cell 135 1287-1298.

Bui HT, Kwon DN, Kang MH, Oh MH, Park MR, Park WJ, Paik SS, Van Thuan N \& Kim JH 2012 Epigenetic reprogramming in somatic cells induced by extract from germinal vesicle stage pig oocytes. Development 139 4330-4340.

Capecchi MR 1989 Altering the genome by homologous recombination. Science 244 1288-1292.

Chen J, Liu H, Liu J, Qi J, Wei B, Yang J, Liang H, Chen Y, Wu Y, Guo L, Zhu J, Zhao X, Peng T, Zhang Y, Chen 
S, Li X, Li D, Wang T \& Pei D 2013 H3K9 methylation is a barrier during somatic cell reprogramming into iPSCs. Nat Genet. 45 34-42.

Chen J, Liu J, Han Q, Qin D, Xu J, Chen Y, Yang J, Song H, Yang D, Peng M, He W, Li R, Wang H, Gan Y, Ding K, Zeng L, Lai L, Esteban MA \& Pei D 2010 Towards an optimized culture medium for the generation of mouse induced pluripotent stem cells. J Biol Chem 285 31066-31072.

Chen LR, Shiue YL, Bertolini L, Medrano JF, BonDurant RH \& Anderson GB 1999 Establishment of pluripotent cell lines from porcine preimplantation embryos. Theriogenology 52 195-212(118).

Clarke DL, Johansson CB, Wilbertz J, Veress B, Nilsson E, Karlstrom H, Lendahl U \& Frisen J 2000 Generalized potential of adult neural stem cells. Science $\mathbf{2 8 8}$ 1660-1663.

Esteban MA, Xu J, Yang J, Peng M, Qin D, Li W, Jiang Z, Chen J, Deng K, Zhong M, Cai J, Lai L \& Pei D 2009 Generation of induced pluripotent stem cell lines from tibetan miniature pig. J Biol Chem 284 17634-17640.

Evans MJ \& Kaufman MH 1981 Establishment in culture of pluripotential cells from mouse embryos. Nature 292 154-156.

Ezashi T, Telugu BP, Alexenko AP, Sachdev S, Sinha S \& Roberts RM 2009 Derivation of induced pluripotent stem cells from pig somatic cells. Proc Natl Acad Sci U S A 106 10993-10998.

Ezashi T, Telugu BP \& Roberts RM 2012 Induced pluripotent stem cells from pigs and other ungulate species: an alternative to embryonic stem cells? Reprod Domest Anim 47 Suppl 4 92-97.

Fan N, Chen J, Shang Z, Dou H, Ji G, Zou Q, Wu L, He L, Wang F, Liu K, Liu N, Han J, Zhou Q, Pan D, Yang D, Zhao B, Ouyang Z, Liu Z, Zhao Y, Lin L, Zhong C, Wang Q, Wang S, Xu Y, Luan J, Liang Y, Yang Z, Li J, Lu C, Vajta G, Li Z, Ouyang H, Wang H, Wang Y, Yang Y, Wei H, Luan Z, Esteban MA, Deng H, Yang H, Pei D, Li N, Pei G, Liu L, Du Y, Xiao L \& Lai L 2013 Piglets cloned from induced pluripotent stem cells. Cell Res 23 162-166.

Fujishiro SH, Nakano K, Mizukami Y, Azami T, Arai Y, Matsunari $H$, Ishino $R$, Nishimura $T$, Watanabe $M$, Abe T, Furukawa Y, Umeyama K, Yamanaka S, Ema M, Nagashima H \& Hanazono Y 2013 Generation of Naive-Like Porcine-Induced Pluripotent Stem Cells Capable of Contributing to Embryonic and Fetal Development. Stem Cells Dev. 22 473-283.

Gandolfi F, Vanelli A, Pennarossa G, Rahaman M, Acocella F \& Brevini TA 2011 Large animal models for cardiac stem cell therapies. Theriogenology 75 1416-1425.

Golovan SP, Meidinger RG, Ajakaiye A, Cottrill M, Wiederkehr MZ, Barney DJ, Plante C, Pollard JW, Fan MZ, Hayes MA, Laursen J, Hjorth JP, Hacker RR, Phillips JP \& Forsberg CW 2001 Pigs expressing salivary phytase produce low-phosphorus manure. Nat Biotechnol 19 741-745.

Greber B, Wu G, Bernemann C, Joo JY, Han DW, Ko K, Tapia N, Sabour D, Sterneckert J, Tesar P \& Scholer
HR 2010 Conserved and divergent roles of FGF signaling in mouse epiblast stem cells and human embryonic stem cells. Cell Stem Cell 6 215-226.

Gu M, Nguyen PK, Lee AS, Xu D, Hu S, Plews JR, Han L, Huber BC, Lee WH, Gong Y, de Almeida PE, Lyons J, Ikeno F, Pacharinsak C, Connolly AJ, Gambhir SS, Robbins RC, Longaker MT \& Wu JC 2012 Microfluidic single-cell analysis shows that porcine induced pluripotent stem cell-derived endothelial cells improve myocardial function by paracrine activation. Circ Res 111 882-893.

Hanna J, Cheng AW, Saha K, Kim J, Lengner CJ, Soldner F, Cassady JP, Muffat J, Carey BW \& Jaenisch R 2010a Human embryonic stem cells with biological and epigenetic characteristics similar to those of mouse ESCs. Proc Natl Acad Sci U S A 107 9222-9227.

Hanna J, Markoulaki S, Mitalipova M, Cheng AW, Cassady JP, Staerk J, Carey BW, Lengner CJ, Foreman R, Love J, Gao Q, Kim J \& Jaenisch R 2009 Metastable pluripotent states in NOD-mouse-derived ESCs. Cell Stem Cell 4 513-524.

Hanna JH, Saha K \& Jaenisch R 2010b Pluripotency and cellular reprogramming: facts, hypotheses, unresolved issues. Cell 143 508-525.

Haraguchi S, Kikuchi K, Nakai M \& Tokunaga T 2012 Establishment of Self-renewing Porcine Embryonic Stem Cell-like Cells by Signal Inhibition. J Reprod Dev 58 707-716.

Huang B, Li T, Alonso-Gonzalez L, Gorre R, Keatley S, Green A, Turner P, Kallingappa PK, Verma V \& Oback B 2011 A virus-free poly-promoter vector induces pluripotency in quiescent bovine cells under chemically defined conditions of dual kinase inhibition. PLOS ONE 6 e24501.

Karpowicz P, Inoue T, Runciman S, Deveale B, Seaberg R, Gertsenstein M, Byers L, Yamanaka Y, Tondat S, Slevin J, Hitoshi S, Rossant J \& van der Kooy D 2007 Adhesion is prerequisite, but alone insufficient, to elicit stem cell pluripotency. J Neurosci 27 5437-5447.

Klymiuk N, Aigner B, Brem G \& Wolf E 2010 Genetic modification of pigs as organ donors for xenotransplantation. Mol Reprod Dev 77 209-221.

Koller BH \& Smithies O 1992 Altering genes in animals by gene targeting. Annu Rev Immunol 10 705-730.

Li M, Zhang D, Hou Y, Jiao L, Zheng X \& Wang WH 2003 Isolation and culture of embryonic stem cells from porcine blastocysts. Mol Reprod Dev 65 429-434.

Li P, Tong C, Mehrian-Shai R, Jia L, Wu N, Yan Y, Maxson RE, Schulze EN, Song H, Hsieh CL, Pera MF \& Ying QL 2008 Germline competent embryonic stem cells derived from rat blastocysts. Cell 135 1299-1310.

Liu K, Ji G, Mao J, Liu M, Wang L, Chen C \& Liu L 2012 Generation of Porcine-Induced Pluripotent Stem Cells by Using OCT4 and KLF4 Porcine Factors. Cell Reprogram 14 505-513.

Martin GR 1981 Isolation of a pluripotent cell line from early mouse embryos cultured in medium conditioned by teratocarcinoma stem cells. Proc Natl Acad Sci U $S$ A 78 7634-7638.

Matsunari H \& Nagashima H 2009 Application of 
genetically modified and cloned pigs in translational research. J Reprod Dev 55 225-230.

Mazhari R \& Hare JM 2012 Translational findings from cardiovascular stem cell research. Trends Cardiovasc Med 22 1-6.

Mueller S, Prelle K, Rieger N, Petznek H, Lassnig C, Luksch U, Aigner B, Baetscher M, Wolf E, Mueller M \& Brem G 1999 Chimeric pigs following blastocyst injection of transgenic porcine primordial germ cells. Mol Reprod Dev 54 244-254.

Nichols J \& Smith A 2009 Naive and primed pluripotent states. Cell Stem Cell 4 487-492.

Notarianni E, Laurie S, Moor RM \& Evans MJ 1990 Maintenance and differentiation in culture of pluripotential embryonic cell lines from pig blastocysts. J Reprod Fertil Suppl 41 51-56.

Piedrahita JA, Moore K, Oetama B, Lee CK, Scales N, Ramsoondar J, Bazer FW \& Ott T 1998 Generation of transgenic porcine chimeras using primordial germ cell-derived colonies. Biol Reprod 58 1321-1329.

Rodriguez A, Allegrucci C \& Alberio R 2012 Modulation of Pluripotency in the Porcine Embryo and iPS Cells. PLoS One 7 e49079.

Rogers CS, Stoltz DA, Meyerholz DK, Ostedgaard LS, Rokhlina T, Taft PJ, Rogan MP, Pezzulo AA, Karp PH, Itani OA, Kabel AC, Wohlford-Lenane CL, Davis GJ, Hanfland RA, Smith TL, Samuel M, Wax D, Murphy CN, Rieke A, Whitworth K, Uc A, Starner TD, Brogden KA, Shilyansky J, McCray PB, Jr., Zabner J, Prather RS \& Welsh MJ 2008 Disruption of the CFTR gene produces a model of cystic fibrosis in newborn pigs. Science 321 1837-1841.

Rui R, Shim H, Moyer AL, Anderson DL, Penedo CT, Rowe JD, BonDurant RH \& Anderson GB 2004 Attempts to enhance production of porcine chimeras from embryonic germ cells and preimplantation embryos. Theriogenology 61 1225-1235.

Shim H, Gutierrez-Adan A, Chen LR, BonDurant RH, Behboodi E \& Anderson GB 1997 Isolation of pluripotent stem cells from cultured porcine primordial germ cells. Biol Reprod 57 1089-1095.

Silva J, Barrandon O, Nichols J, Kawaguchi J, Theunissen TW \& Smith A 2008 Promotion of reprogramming to ground state pluripotency by signal inhibition. PLoS Biol 6 e253.

Staunstrup NH, Madsen J, Primo MN, Li J, Liu Y, Kragh PM, Li R, Schmidt M, Purup S, Dagnaes-Hansen F, Svensson L, Petersen TK, Callesen H, Bolund L \& Mikkelsen JG 2012 Development of transgenic cloned pig models of skin inflammation by DNA transposondirected ectopic expression of human beta1 and alpha2 integrin. PLoS One 7 e36658.

Swindle MM 2007 Swine in the laboratory: Surgery, anesthesia, imaging, and experimental techniques. Boca Raton, FL.

Takahashi K, Tanabe K, Ohnuki M, Narita M, Ichisaka T, Tomoda K \& Yamanaka S 2007 Induction of pluripotent stem cells from adult human fibroblasts by defined factors. Cell 131 861-872.

Takahashi K \& Yamanaka S 2006 Induction of pluripotent stem cells from mouse embryonic and adult fibroblast cultures by defined factors. Cell 126 663-676.

Talbot NC \& Blomberg le A 2008 The pursuit of ES cell lines of domesticated ungulates. Stem Cell Rev 4 235-254.

Tan G, Ren L, Huang Y, Tang X, Zhou Y, Li D, Song H, Ouyang H \& Pang D 2012 Isolation and culture of embryonic stem-like cells from pig nuclear transfer blastocysts of different days. Zygote 20 347-352.

Telugu BP, Ezashi T \& Roberts RM 2010 Porcine induced pluripotent stem cells analogous to naive and primed embryonic stem cells of the mouse. Int J Dev Biol $\mathbf{5 4}$ 1703-1711.

Telugu BP, Ezashi T, Sinha S, Alexenko AP, Spate L, Prather RS \& Roberts RM 2011 Leukemia inhibitory factor (LIF)-dependent, pluripotent stem cells established from inner cell mass of porcine embryos. J Biol Chem 286 28948-28953.

Tesar PJ, Chenoweth JG, Brook FA, Davies TJ, Evans EP, Mack DL, Gardner RL \& McKay RD 2007 New cell lines from mouse epiblast share defining features with human embryonic stem cells. Nature 448 196-199.

Thomson AJ, Pierart H, Meek S, Bogerman A, Sutherland L, Murray H, Mountjoy E, Downing A, Talbot R, Sartori C, Whitelaw CB, Freeman TC, Archibald AL \& Burdon T 2012 Reprogramming pig fetal fibroblasts reveals a functional LIF signaling pathway. Cell Reprogram 14 112-122.

Vackova I, Ungrova A \& Lopes F 2007 Putative embryonic stem cell lines from pig embryos. J Reprod Dev 53 1137-1149.

Vassiliev I, Vassilieva S, Beebe LF, Harrison SJ, Mcllfatrick SM \& Nottle MB 2010 In vitro and in vivo characterization of putative porcine embryonic stem cells. Cell Reprogram 12 223-230.

Vassiliev I, Vassilieva S, Truong KP, Beebe LF, Mcllfatrick SM, Harrison SJ \& Nottle MB 2011 Isolation and in vitro characterization of putative porcine embryonic stem cells from cloned embryos treated with trichostatin A. Cell Reprogram 13 205-213.

West FD, Terlouw SL, Kwon DJ, Mumaw JL, Dhara SK, Hasneen K, Dobrinsky JR \& Stice SL 2010 Porcine Induced Pluripotent Stem Cells Produce Chimeric Offspring. Stem Cells Dev 19 1211-1220.

West FD, Uhl EW, Liu Y, Stowe H, Lu Y, Yu P, GallegosCardenas A, Pratt SL \& Stice SL 2011 Brief report: chimeric pigs produced from induced pluripotent stem cells demonstrate germline transmission and no evidence of tumor formation in young pigs. Stem Cells 29 1640-1643.

Wheeler MB 1994 Development and validation of swine embryonic stem cells: a review. Reprod Fertil Dev 6 563-568.

Whyte JJ \& Prather RS 2011 Genetic modifications of pigs for medicine and agriculture. Mol Reprod Dev 78 879-891.

Wolf XA, Rasmussen MA, Schauser K, Jensen AT, Schmidt M \& Hyttel P 2011 OCT4 expression in outgrowth colonies derived from porcine inner cell masses and epiblasts. Reprod Domest Anim 46 385-392. 
Wu Z, Chen J, Ren J, Bao L, Liao J, Cui C, Rao L, Li H, Gu Y, Dai H, Zhu H, Teng X, Cheng L \& Xiao L 2009 Generation of pig induced pluripotent stem cells with a drug-inducible system. J Mol Cell Biol 1 46-54.

Xu Y, Zhu X, Hahm HS, Wei W, Hao E, Hayek A \& Ding S 2010 Revealing a core signaling regulatory mechanism for pluripotent stem cell survival and self-renewal by small molecules. Proc Natl Acad Sci U S A 107 8129-8134.

Yang JY, Mumaw JL, Liu Y, Stice SL \& West FD 2012 SSEA4 Positive Pig Induced Pluripotent Stem Cells
Are Primed for Differentiation into Neural Cells. Cell Transplant.

Yu J, Vodyanik MA, Smuga-Otto K, Antosiewicz-Bourget J, Frane JL, Tian S, Nie J, Jonsdottir GA, Ruotti V, Stewart R, Slukvin, II \& Thomson JA 2007 Induced pluripotent stem cell lines derived from human somatic cells. Science 318 1917-1920.

Zhou L, Wang W, Liu Y, Fernandez de Castro J, Ezashi T, Telugu BP, Roberts RM, Kaplan HJ \& Dean DC 2011 Differentiation of induced pluripotent stem cells of swine into rod photoreceptors and their integration into the retina. Stem Cells 29 972-980. 